\title{
Virtual Edukasi Kesehatan Gigi Dan Mulut Pada Kelompok Lanjut Usia Di Masa Pandemi Covid-19
}

\author{
https://doi.org/10.32509/abdimoestopo.v4i02.1403
}

\author{
Yufitri Mayasari ${ }^{*}$, Elin Hertiana ${ }^{2}$, Sarah Mersil $^{3}$, Poetry Oktanauli ${ }^{4}$ \\ Fakultas Kedokteran Gigi, Universitas Prof. Dr.Moestopo (Beragama) \\ Jl. Bintaro Permai Raya No. III, Bintaro, Jakarta, Indonesia \\ *E-mail korespondensi : yufitrimayasari@dsn.moestopo.ac.id
}

\begin{abstract}
$\overline{\text { Abstract - During the covid-19 pandemic, health promotion program were slightly hampered because }}$ there were rules for social distancingto break the chain of transmission the SARS-COV 2 virus. Providing remote education using online media is the best solution. The purpose of this paper is to explain educational activities in elderly groups using online media Zoom meeting. This project carried out by Faculty of Dentistry Universitas Prof.Dr.Moestopo (Beragama) in collaboration with the Forum Komunikasi Lanjut Usia, Binaan Suku Dinas Kesehatan Jakarta Selatan on November 3rd 2020. This activity was attended by 82 participants, most of them were women (95\%). Participant were given education about dental and oral health in elderly, including : (1) The physyologiccal condition of oral cavity in elderly, (2) Dental and oral diseases in elderly, and (3) How to maintain daily dental and oral health in elderly. At the end of the presentasion session, there was discussion about the material presented. At the end of virtual education, feedback was carried our as an evaluation using a google form. The result for the way of presentation, $68 \%$ rated very good and $20 \%$ rated good. And for the material presented, $78 \%$ rated very good and $21 \%$ rated good.
\end{abstract}

Keywords : geriatric, virtual education, dental health, covid-19

Abstrak - Pada masa pandemi Covid-19 kegiatan promosi kesehatan sedikit terhambat karena ada aturan menjaga jarak sosial atau social distancing guna memutus mata rantai penularan virus SARSCov 2. Hal ini mengakibatkan kegiatan promosi kesehatan tidak dapat berjalan dengan tatap muka. Pemberian edukasi secara jarak jauh menggunakan media daring merupakan solusi terbaik agar program promosi kesehatan terutama terkait gigi dan mulut dapat tetap terlaksana. Tujuan dari penulisan makalah ini adalah untuk menjelaskan kegiatan edukasi pada kelompok lanjut usia menggunakan media daring Zoom cloud meeting yang dilakukan oleh FKG Universitas Prof.Dr.Moestopo (Beragama) bekerja sama dengan Forum Komunikasi Lanjut Usia Suku Dinas Kesehatan Jakarta Selatan pada tanggal 3 November 2020. Kegiatan ini diikuti oleh anggota Forum Komunikasi Lanjut Usia Sudinkes Jak-Sel, anggota Muslimat Nahdlatul Ulama serta masyarakat umum yang seluruhnya berjumlah 82 peserta dimana sebagian besar adalah wanita (95\%). Peserta diberikan edukasi mengenai kesehatan gigi dan mulut lansia meliputi : (1) Kondisi fisiologis rongga mulut lansia, (2) Penyakit gigi dan mulut yang sering dialami lansia, (3) Cara menjaga kesehatan gigi dan mulut sehari-hari untuk lansia. Pada akhir sesi, diadakan tanya jawab seputar materi yang disampaikan. Pada akhir kegiatan dilakukan umpan balik sebagai evaluasi kegiatan menggunakan google form. Hasilnya untuk cara penyajian $68 \%$ peserta menilai sangat baik dan $20 \%$ peserta menilai baik. Sedangkan untuk materi yang disampaikan $78 \%$ peserta menilai sangat baik dan $21 \%$ peserta menilai baik.

Kata Kunci : lansia, edukasi virtual, gigi dan mulut, covid-19

\section{PENDAHULUAN}

Menurut Undang-Undang Republik Indonesia No. 13 Tahun 1998 pasal 1 ayat 2 tentang kesejahteraan lanjut usia, lanjut usia adalah seseorang yang telah mencapai usia enam puluh tahun ke atas.(Indonesia, 2006) Proporsi jumlah lanjut usia terus berkembang di seluruh dunia, terutama di negara berkembang. Pertumbuhan jumlah lanjut usia cenderung lebih cepat 
dibandingkan dengan kelompok usia lainnya.(Othman et al., 2006) Secara global pada tahun 2017 menurut data Persatuan Bangsa-Bangsa (PBB), jumlah penduduk usia 60 tahun keatas yaitu 962 juta, dua kali lebih besar dibandingkan tahun 1980 yang hanya berjumlah 382 juta. Jumlah lanjut usi ini diperkirakan akan naik dua kali lipat kembali pada tahun 2050 yang diprediksi mencapai hingga 2.1 milyar.(Statistik, 2013).

Kementerian Kesehatan mencatat adanya peningkatan jumlah penduduk lanjut usia di Indonesia, yakni dari 18 juta jiwa (7,6\%) pada 2010 menjadi 25,9 juta jiwa (9,7\%) pada 2019 seperti terlihat pada Gambar 1. Jumlahnya diprediksi akan terus meningkat hingga 48,2 juta jiwa $(15,8 \%)$ pada 2035.(Statistik, 2013). Jumlah penduduk lanjut usia yang meningkat ini merupakan dampak dari keberhasilan pembangunan terutama di bidang kesehatan.

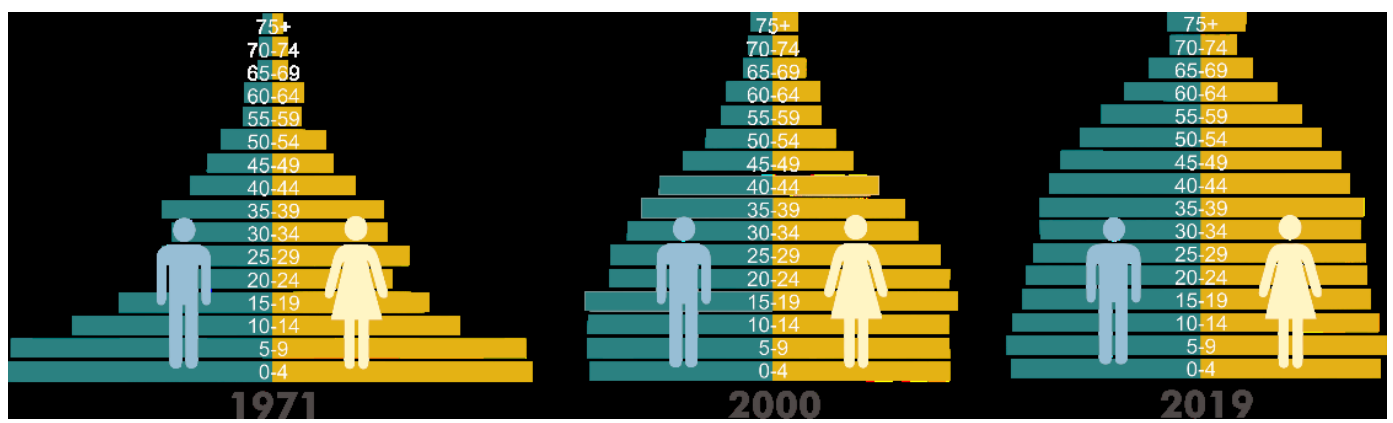

Gambar 1. Piramida Penduduk Indonesia Tahun 1971, 2000, 2019

Dalam bidang kesehatan, untuk menghadapi populasi lanjut usia yang begitu besar, perlu diperhatikan kesehatan fisik dan psikologis serta kualitas yang berhubungan dengan kesehatan hidup. (Indonesia, 2006) Selain kesehatan umum pada lanjut usia, kesehatan gigi dan mulut juga merupakan elemen penting dari kesehatan umum dan kualitas hidup, namun kesehatan gigi dan mulut masih sering terabaikan dalam program kesehatan umum.(Statistik, 2013)(Indonesia, 2006). Berdasarkan data riset kesehatan dasar (Riskesdas) 2018, menyatakan bahwa prevalensi terbesar masalah gigi di Indonesia adalah gigi rusak/berlubang/sakit (45,3\%). Peningkatan prevalensi antara lain terjadi pada populasi berumur lebih dari 65 tahun.(H. Wahjudi Nugroho, 2009) Penyakit ini kemungkinan akan mempengaruhi kualitas hidup terkait kesehatan mulut karena karies gigi menyebabkan nyeri, ketidaknyamanan fisik dan psikologis.

Kesehatan gigi dan mulut menjadi salah satu masalah yang berimplikasi negatif terhadap kesehatan secara keseluruhan sehingga pada akhirnya mempengaruhi kualitas hidup pada lanjut usia. Penyakit mulut pada lanjut usia tidak hanya menyebabkan nyeri, berkurangnya kemampuan mengunyah dan efek merugikan pada pengucapan dan penampilan fisik tetapi juga mempengaruhi kesehatan umum dan meningkatkan risiko penyakit saraf, endokrin, kardiovaskuler, dan pernapasan. Masalah kesehatan mulut juga terkait dengan perubahan dalam pemilihan makanan, penurunan kualitas gizi dan penurunan kualitas hidup.(Othman et al., 2006)

Dalam peningkatan kualitas hidup lansia secara keseluruhan perlu diperhatikan akses yang tepat ke perawatan kesehatan mulut bahkan pada orang lanjut usia dengan multimorbiditas.(Othman et al., 2006) Sementara itu, untuk meningkatkan kualitas hidup lansia terkait kesehatan gigi dan mulut harus diketahui faktor kesehatan mulut mana yang berkontribusi pada peningkatan kualitas hidup.(Jill C. Cash \& Cheryl A. Glass, 2019)

Pada masa pandemi Covid-19 terdapat kebijakan pemerintah untuk menjaga jarak sosial atau social distancing guna memutus mata rantai penularan virus SARS-Cov 2. Hal ini mengakibatkan kegiatan promosi kesehatan tidak dapat berjalan dengan tatap muka. Pemberian informasi dan edukasi secara jarak jauh menggunakan media daring merupakan solusi terbaik agar program promosi kesehatan dapat tetap terlaksana, terutama dalam usaha untuk mencegah penyebaran COVID-19 lebih jauh. Pemberian informasi dan edukasi mengenai pencegahan 
penularan COVID-19 banyak dilakukan oleh berbagai pihak, baik melalui media massa, poster, spanduk, maupun secara virtual kepada masyarakat. Salah satunya adalah edukasi mengenai pencegahan penularan Covid-19 pada komunitas musik di Jabodetabek secara daring yang dilakukan oleh FKG Universitas Trisakti. (Andayani et al., 2021). Tujuan dari penulisan makalah ini adalah untuk menjelaskan kegiatan edukasi pada kelompok lanjut usia menggunakan media daring yang dilakukan oleh FKG Universitas Prof.Dr.Moestopo (Beragama) bekerja sama dengan Forum Komunikasi Lanjut Usia SUku Dinas Kesehatan Jakarta Selatan.

\section{METODE PELAKSANAAN}

Kegiatan edukasi Kesehatan gigi dan mulut untuk kelompok lanjut usia ini dilakukan secara daring menggunakan Zoom meeting. Sasaran kegiatan ini adalah kelompok lanjut usia dan anggota muslimat Nahdlatul Ulama yang berjumlah 82 orang. Peserta kegiatan dibagi dalam 3 breakout room zoom meeting, di dalam setiap breakout room terdapat 5 dokter gigi yang bertugas memberikan edukasi Kesehatan gigi dan mulut. Hal ini bertujuan materi yang diberikan akan lebih dapat dipahami oleh peserta apabila edukasi dilakukan dalam kelompok kecil di dalam breakout room. Peserta kegiatan akan mendapatkan edukasi mengenai Kesehatan gigi dan mulut Lansia meliputi : a. Kondisi fisiologis rongga mulut lansia $b$. Penyakit gigi dan mulut yang sering dialami Lansia c. Cara menjaga Kesehatan gigi dan mulut sehari-hari untuk Lansia. Pada setiap akhir sesi dilakukan tanya jawab sebagai sarana para peserta. Formulir terkait evaluasi kegiatan dibagikan kepada peserta menggunakan aplikasi google form yang berisi pertanyaan terkait identitas, usia, jenis kelamin, kepuasan atas materi, dan saran untuk perbaikan di masa yang akan datang.

\section{HASIL DAN PEMBAHASAN}

Kegiatan Virtual Edukasi Kesehatan Gigi dan Mulut Lansia dilaksanakan secara daring menggunakan Zoom meeting pada hari Selasa, 3 November 2020 pukul 10.00 - 12.00 WIB. Kegiatan ini merupakan kerjasama antara FKG UPDM(B) dengan Forum Komunikasi Lanjut Usia, Suku Dinas Kesehatan Jakarta Selatan. Peserta kegiatan adalah anggota Forum Komunikasi Lanjut Usia Sudinkes Jak-Sel, anggota Muslimat Nahdlatul Ulama serta masyarakat umum yang seluruhnya berjumlah 82 peserta. Dari keseluruhan peserta, 95\% peserta merupakan perempuan, sementara itu 5\% nya merupakan laki-laki. Adapun gambaran deskriptif peserta kegiatan berdasarkan jenis kelamin dapat dilihat pada Diagram 1 berikut ini

\section{DESKRIPSI PESERTA BERDASARKAN JENIS KELAMIN}

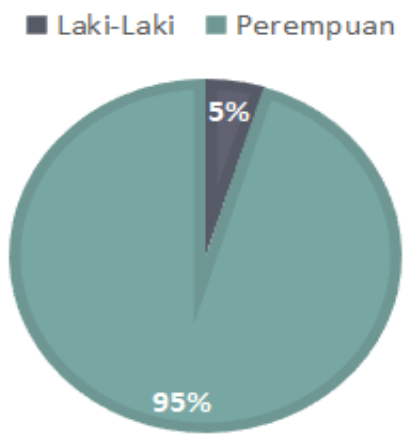

Diagram 1. Deskripsi peserta berdasarkan jenis kelamin $(n=82)$

Dari 82 peserta yang mengikuti kegiatan ini dapat dibagi menjadi 3 kelompok usia yaitu 21-40 tahun, 41-60 tahun, dan 61-80 tahun. (Tabel 1) 
Tabel 1. Deskripsi peserta berdasarkan usia $(n=82)$

\begin{tabular}{ccc}
\hline Kelompok Usia & Frekuensi & Persentase \\
\hline $21-40$ tahun & 26 & 31,7 \\
$41-60$ tahun & 30 & 36,6 \\
$61-80$ tahun & 26 & 31,7 \\
\hline
\end{tabular}

Kegiatan dimulai dengan pembukaan dan kata sambutan dari Dekan FKG UPDM (B) dan perwakilan Forum Komunikasi Lansia, Sudinkes Jakarta Selatan. Pada acara di main room diputarkan video edukasi mengenai cara menjaga kesehatan tubuh serta rongga mulut lansia sehari-hari. (Gambar 2).

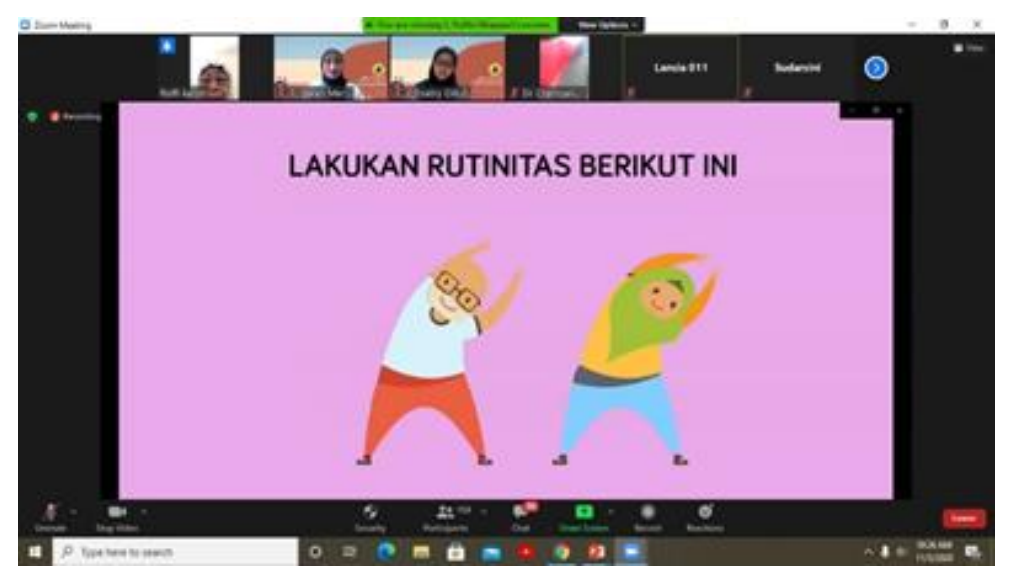

Gambar 2. Video edukasi cara menjaga kesehatan tubuh serta rongga mulut lansia sehari-hari

Setelah itu peserta dibagi ke dalam 3 breakout room zoom meeting (Gambar 3) untuk mendengarkan edukasi dari para dokter gigi FKG UPDM (B) mengenai kesehatan gigi dan mulut lansia yang meliputi : kondisi fisiologis rongga mulut lansia, penyakit gigi dan mulut yang sering dialami lansia, serta cara menjaga kesehatan gigi dan mulut untuk lansia. Terakhir diadakan sesi tanya jawab antara dokter gigi dengan peserta kegiatan. Acara berlangsung dengan lancar dan baik, terbukti dengan banyaknya peserta yang hadir dan yang bertanya mengenai kesehatan gigi dan mulut, terutama di masa pandemi seperti sekarang karena sebagian besar peserta masih takut untuk datang ke dokter gigi. Sesi edukasi dan tanya jawab di breakout room berlangsung selama 90 menit.
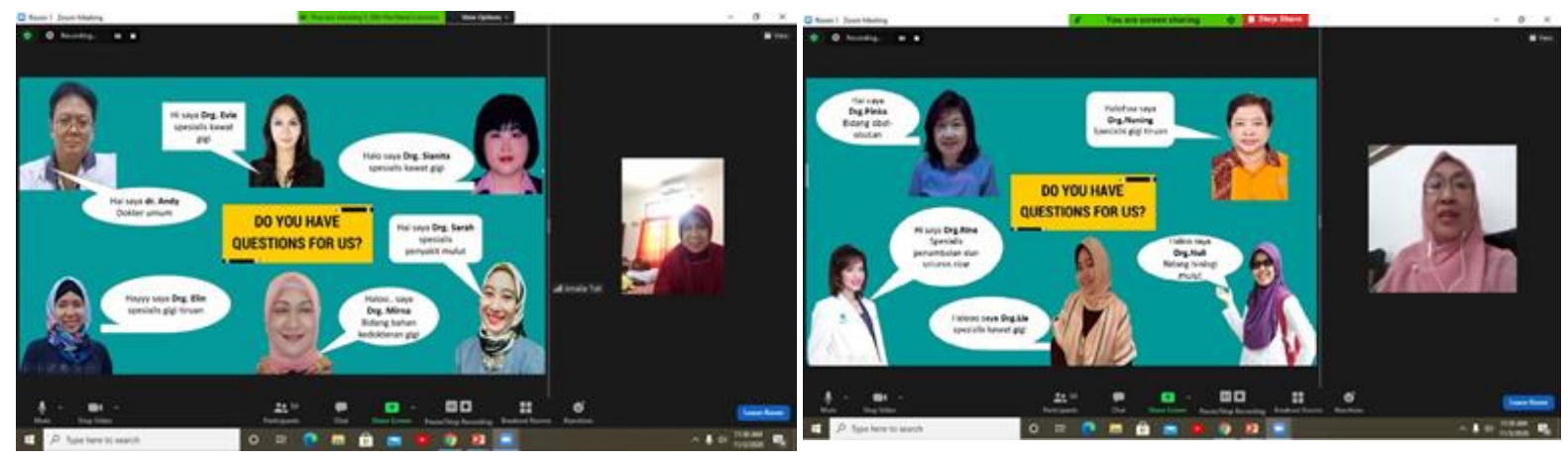


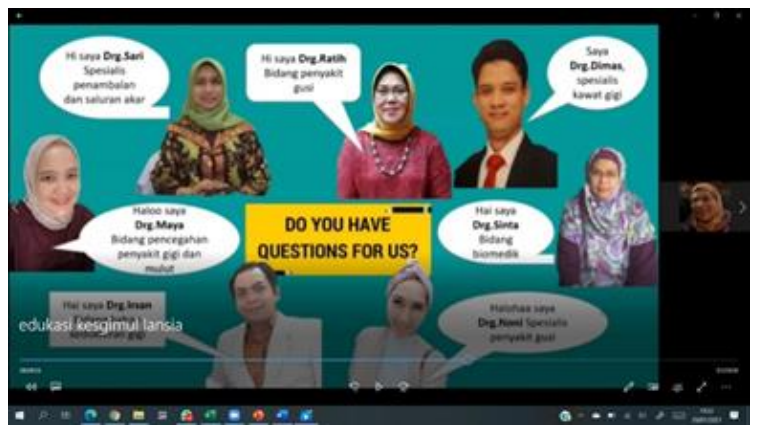

Gambar 3. Dokumentasi kegiatan pada breakout room 1,2, dan 3

Setelah sesi edukasi dan tanya jawab selesai, peserta kembali ke main room untuk menyaksikan video persembahan FKG UPDM (B) mengenai edukasi kesehatan gigi dan mulut lansia serta bersama-sama melakukan senam cuci tangan (Gambar 4).

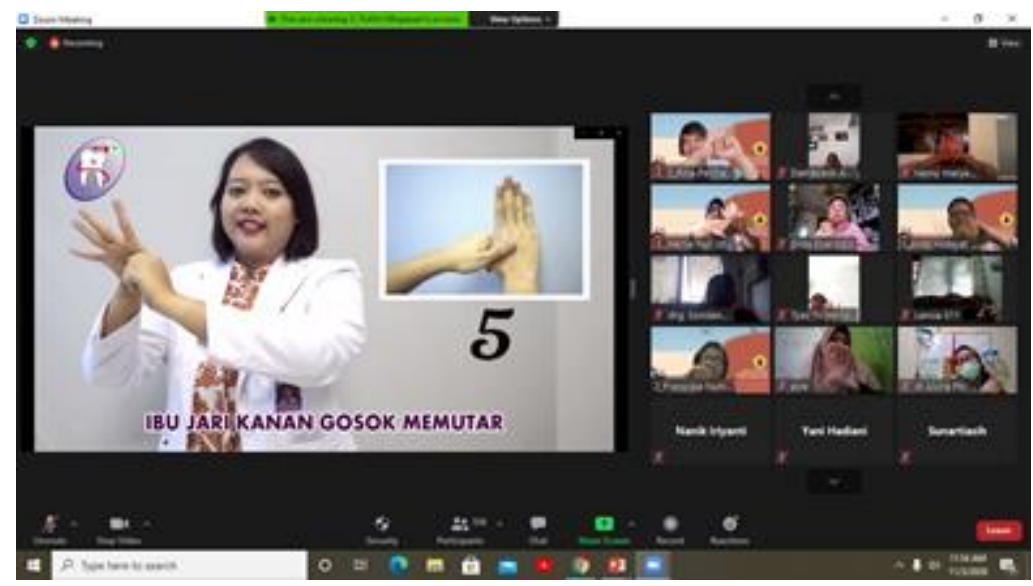

Gambar 4. Video edukasi mencuci tangan dari RSGM FKG UPDMB

Para peserta sangat bersemangat untuk mengikuti senam cuci tangan ini. Bahkan mereka minta untuk diulang sekali lagi. Setelah itu, acara ditutup dengan pembacaan doa serta sesi foto bersama panitia dan peserta.

Meningkatnya prevalensi penyakit kronis pada lansia, ditambah dengan menurunnya fungsi normal dengan penambahan usia, hilangnya fungsi, ketergantungan dengan orang lain, isolasi, disabilitas dan menurunnya kualitas hidup dan kepuasan pada lansia. Kualitas hidup adalah goal terbesar pada suatu kondisi sehat guna memperbaiki kehidupan kesehatan lansia. Goal kesehatan termasuk konsep yang multidisiplin termasuk fisik, psikologis, sosial, mental dan gejala terkait penyakit atau perubahan dalam perawatan. (Shokouhi et al., 2019) Usia lanjut terkait dengan perubahan fisiologis, nafsu makan menurun, masalah nutrisi, masalah gigi dan mulut seperti kehilangan gigi, sulit menelan dan mengunyah makanan, diikuti dengan beberapa penyakit kronis. Fenomena bertambahnya usia menambah beban semua penyakit kronis, termasuk penyakit gigi dan mulut. Masalah kesehatan mulut memiliki konsekuensi sosial, ekonomi dan psikologi yang mempengaruhi kualitas hidup lansia. Kualitas hidup terkait kesehatan rongga mulut adalah bagaimana seseorang menilai status mental, psikologis, status sosial yang dipengaruhi oleh kesehatan rongga mulutnya.(Shokouhi et al., 2019)

Populasi geriatri dapat dibagi menjadi 3 kelas, dalam hal melakukan perawatan kesehatan gigi dan mulut, diantara yaitu : 1) Lansia yang mandiri secara fungsional. Mereka memiliki kemampuan mengemudi dan / atau menggunakan transportasi umum sendiri untuk 
mengakses fasilitas kesehatan. Dokter gigi umum dapat merawat dengan aman pada kelompok ini, dimana dokter gigi harus memiliki pengetahuan yang diperlukan tentang fisiologi, kedokteran dan farmakologi yang berhubungan dengan pasien penyakit kronis dan pengaruhnya terhadap perawatan gigi. 2) Lansia yang lemah. Kelompok ini memiliki lebih banyak riwayat sistemik dan farmakoterapi yang kompleks, yang mungkin memerlukan konsultasi dengan dokter yang merawatnya sebelum perawatan gigi dan mulut invasif. Kelompok ini termasuk orang yang masih dapat mengakses fasilitas kesehatan, meski dengan bantuan seseorang. 3) Lansia yang bergantung secara fungsional, yaitu lansia yang tinggal di rumah atau institusi kesehatan. Cara terbaik untuk memberikan pelayanan kesehatan mulut bagi kelompok ini mungkin langsung di lingkungan mereka sendiri.(Shreshtha, 2020)Lansia yang lemah dan tergantung secara fungsional banyak hambatan saat mengakses fasilitas kesehatan untuk mendapatkan pelayan kesehatan gigi dan mulut. beberapa diantara hambatannya adalah : 1) Hambatan sosial ekonomi yaitu a. Kendala keuangan, b. Kurangnya asuransi kesehatan gigi dan mulut, c. Kurangnya dukungan sosial; 2) Hambatan umum yang berhubungan dengan kesehatan, yaitu : a. Adanya beberapa penyakit penyerta, b. Polifarmasi, c. Gangguan kognitif seperti demensia, d. Mobilitas yang berkurang, e. Kemandirian yang terbatas; 3) Masalah kesehatan mulut yang membuat perawatan gigi lebih banyak, yaitu : a. Xerostomia, b. Karies akar, c. Luasnya kerusakan gigi yang harus direstorasi, d. Ketidakmampuan untuk menjaga kebersihan mulut secara mandiri. (Shreshtha, 2020)

Dari akhir tahun 2019, dunia mengalami pandemi penyakit infeksi aerosol yaitu Covid19, juga di Indonesia mulai ditemukan kasusnya sejak Maret 2020. Individu lanjut usia memiliki risiko yang sangat fatal bila terinfeksi SARS Corona virus 2 (CoV-2), karena sistem imun yang mulai menurun dan memiliki komorbid sehingga sangat rentan terhadap penyakit infeksi. Prosedur dental banyak menghasilkan produk aerosol, yang dapat menyebarkan infeksi Covid19. Selama pandemi Covid-19, prosedur dental elektif harus diterapkan, hanya tindakan darurat saja yang diindikasikan dapat dilakukan perawatan oleh kebanyakan dokter gigi berpraktik sampai tersedianya ruangan khusus bertekanan negatif, layaknya di rumah sakit. Konsultasi kesehatan gigi dan mulut melalui teledentistry sudah mulai banyak dilakukan untuk menghindari penularan COVID-19 dalam ruang praktek dokter gigi. Protokol perawatan kesehatan lansia yang dirawat di RS dalam waktu lama tidak selalu terintegrasi dengan perawatan kesehatan rongga mulut, tujuannya untuk mengurangi jumlah kunjungan. (Marchini \& Ettinger, 2020). Menurut penelitian Nila Kusuma dkk, tahun 2020 metode edukasi secara daring efektif pada peningkatan pengetahuan responden. Edukasi kesehatan gigi dan mulut sangat tepat bagi suatu komunitas untuk memutus rantai infeksi COVID-19 (Kasuma et al., 2020).

Menjaga kesehatan gigi dan mulut selama masa pandemi COVID-19 sangatlah penting dilakukan untuk menghindari kemungkinan terjadinya kerusakan pada gigi, sehingga tak perlu mengunjungi dokter terkait imbauan untuk tetap di rumah saja. Tujuannya adalah untuk mengoptimalkan sistem kekebalan tubuh. Rongga mulut yang sehat meningkatkan sistem kekebalan tubuh untuk melawan pengganggu lainnya (Liasari \& Lesmana, 2020). Selain itu, keuntungan dari edukasi secara virtual adalah dapat menjangkau peserta lebih luas. Siapa pun yang memiliki akses internet, gawai, serta aplikasi dapat mengikutinya.

Edukasi yang dapat diberikan pada kelompok lansia maupun kelompok lainnya yaitu saran perawatan profilaksis di rumah untuk pemeliharaan kebersihan mulut, diantaranya adalah : 1) Sikat dua kali sehari dengan pasta gigi berfluorida; 2) Pembersihan interdental sesuai anjuran flossing sekali sehari; 3) Batasi asupan gula hingga waktu makan ; 4) Hindari kebiasaan, yang dapat menyebabkan tambalan patah tulang, seperti membuka benda dengan gigi, mengunyah makanan lengket keras dan aktivitas berisiko seperti olahraga fisik tanpa pelindung mulut, 5) Ikuti etika kebersihan sikat gigi yang baik termasuk mencuci tangan sebelum dan setelah menyikat, bilas sikat dengan air panas air setelah digunakan, jangan pernah berbagi sikat 
gigi, dan buang sikat gigi jika pernah mengalami gejala Covid-19, 6) Buatlah janji untuk pergi kontrol ke dokter gigi setelah pandemi selesai. (Shreshtha, 2020)

Pada akhir kegiatan dilakukan umpan balik sebagai evaluasi kegiatan menggunakan google form. Dari hasil umpan balik tersebut diperoleh hasil $68 \%$ peserta menyatakan cara penyajian materi kegiatan tergolong sangat baik, begitu juga dengan materi yang disajikan dianggap sangat baik (78\%). Adapun beberapa saran yang diberikan oleh peserta kegiatan antara lain materi ppt dikirimkan ke peserta, perlu ditambahkan materi tentang kesehatan umum lansia, perlu ditambah sesi pemeriksaan gigi, serta perlunya waktu kegiatan ditambah lebih Panjang. (Tabel 2 dan Grafik 1). Semua masukan dan saran akan menjadi evaluasi bagi penyelenggaraan kegiatan selanjutnya.

Tabel 2. Deskripsi hasil umpan balik peserta kegiatan $(n=82)$

\begin{tabular}{lcc}
\hline & Cara penyajian & Materi yang disajikan \\
\hline Sangat baik & $68 \%$ & $78 \%$ \\
Baik & $20 \%$ & $21 \%$ \\
Sedang & $3 \%$ & - \\
Buruk & - & - \\
Sangat buruk & - & - \\
Tidak menjawab & $7 \%$ & $1 \%$ \\
\hline
\end{tabular}

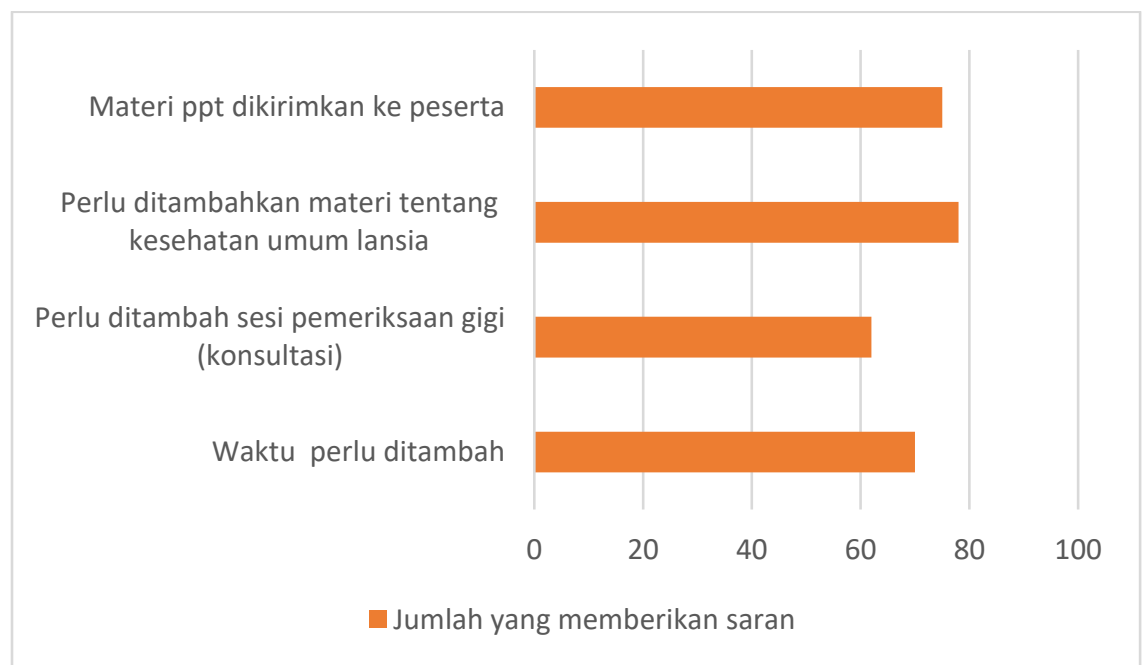

Grafik 1. Rekapitulasi saran yang diberikan peserta kepada panitia

\section{SIMPULAN}

Di masa pandemi covid-19 terdapat keterbatasan dalam melakukan interaksi dengan masyarakat dengan adanya anjuran menjaga protokol kesehatan yang salah satunya adalah social distancing. Oleh karena itu diperlukan alternatif agar kegiatan promosi kesehatan dapat tetap terlaksana, salah satunya dengan melakukan virtual edukasi menggunakan zoom cloud meeting . Pada makalah ini kegiatan virtual edukasi kesehatan gigi dan mulut telah dilaksanakan pada masyarakat kelompok lanjut usia yang tergabung dalam Forum Komunikasi Lanjut Usia di bawah binaan Suku Dinas Kesehatan Jakarta Selatan. Kegiatan ini memberikan manfaat kepada peserta, peserta dapat lebih memahami kondisi fisiologi di rongga mulut serta bagaimana menjaga kesehatan gigi dan mulut dengan baik. Diharapkan kegiatan virtual edukasi seperti ini dapat dilakukan lagi oleh FKG Universitas Prof.Dr.Moestopo (Beragama) dengan mengangkat materi menarik lainnya terkait kesehatan gigi dan mulut. 


\section{Ucapan Terima Kasih}

Penulis mengucapkan terima kasih kepada Forum Komunikasi Lanjut Usia binaan Suku Dinas Kesehatan Jakarta Selatan serta Muslimat Nahdlatul Ulama yang telah berpartisipasi dan berperan aktif demi terselenggaranya kegiatan pengabdian masyarakat ini.

\section{Daftar Pustaka}

Andayani, L.H.A., Sandra, F., Soulisa, A.G., Handoyo, J. (2021) Edukasi Mengenai Pencegahan Penularan Covid-19 pada Komunitas Musik di Jabodetabek Secara Daring. Jurnal Abdi MOESTOPO,4(1),17-24.

H. Wahjudi Nugroho, B. S. S. K. M. (2009). Komunikasi dalam Keperawatan gerontik (M. Ester (ed.)). EGC. https://books.google.co.id/books?id=BHTxm3mVA5EC

Indonesia, D. S. R. (2006). Undang-Undang RI NO 13 Tahun 1998 tentang kesejahteraan lanjut usia. Departemen Sosial. http://www.bphn.go.id/data/documents/98uu013.pdf

Jill C. Cash, M. S. N. A. P. N. F. N. P. B. C., \& Cheryl A. Glass, M. S. N. A. W. B. C. (2019). Adult-Gerontology Practice Guidelines, Second Edition (2nd ed.). Springer Publishing Company. https://books.google.co.id/books?id=O15xDwAAQBAJ

Kasuma, N., Biomed, M., Murniwati, Sumantri, D., Nofika, R., Nelis, S., Susi, \& Fransiska, A. (2020). Effectiveness of online oral health education during the Covid-19 pandemic. Indian Journal of Forensic Medicine and Toxicology, 14(4), 4240-4248. https://doi.org/10.37506/ijfmt.v14i4.12306

Liasari, I., \& Lesmana, H. (2020). Studi Literatur : Pencegahan Penyebaran SARS-CoV-2 Pada Praktik Kedokteran Gigi. Media Kesehatan Gigi, 19(1), 41-46.

Marchini, L., \& Ettinger, R. L. (2020). COVID-19 and geriatric dentistry: What will be the new-normal? Brazilian Dental Science, 23(2), 1-7. https://doi.org/10.14295/bds.2020.v23i2.2226

Othman, W. N. W., Muttalib, K. A., Bakri, R., Doss, J. G., Jaafar, N., Salleh, N. C., \& Chen, S. (2006). Validation of the Geriatric Oral Health Assessment Index (GOHAI) in the Malay language. Journal of Public Health Dentistry, 66(3), 199-204. https://doi.org/10.1111/j.1752-7325.2006.tb02580.x

Shokouhi, E., Mohamadian, H., Babadi, F., Cheraghian, B., \& Araban, M. (2019). Improvement in oral health related quality of life among the elderly: A randomized controlled trial. BioPsychoSocial Medicine, 13(1), 1-11. https://doi.org/10.1186/s13030019-0170-3

Shreshtha, R. (2020). Challenges in Geriatric Dental Patient Management in Covid-19 Pandemic. Journal of Aging and Geriatric Psychiatry, 4(2), 26-27.

Statistik, B. P. (2013). Proyeksi Penduduk Indonesia (Indonesia Population Project) 20102035 (Issue 6). Badan Pusat Statistik. https://doi.org/10.1007/BF00830441 